\title{
Бялт В.С., Чимаров С.Ю. \\ Работа по укреплению служебной дисциплины и законности среди личного состава как вид морально-психологического обеспечения деятельности органов внутренних дел
}

Санкт-Петербургский университет МВД России (Россия, Санкт-Петербург)

doi: $10.18411 / l j-02-2021-124$

idsp: ljournal-02-2021-124

\section{Аннотация}

В статье авторы исследуют вопросы, касающиеся актуальных проблем работы по укреплению служебной дисциплины и законности среди личного состава как одного из видов морально-психологического обеспечения деятельности органов внутренних дел. Анализируя действующие правовые нормы в указанной сфере, авторы, рассматривают основные направления и задачи обозначенной работы, а также формулируют и обосновывают ряд предложения по повышению. эффективности работы по укреплению служебной дисциплины и законности в органах внутренних дел.

Ключевые слова: морально-психологическое обеспечение; воспитание; служебная дисциплина; законность; органы внутренних дел.

\section{Abstract}

In the article, the authors explore issues related to the actual problems of work to strengthen service discipline and legality among the personnel as one of the types of moral and psychological support for the activities of internal affairs bodies. Analyzing the current legal norms in this area, the authors consider the main directions and tasks of the designated work, as well as formulate and justify a number of proposals for improvement, efficiency of work to strengthen official discipline and the rule of law in the internal affairs bodies.

Keywords: moral and psychological support; education; service discipline; legality; internal affairs bodies.

Исследование вопросов, связанных с совершенствованием деятельности органов внутренних дел как одного из основных элементов правоохранительной системы, является одним из условий повышения уровня общественной безопасности и общественного порядка в государстве. Эффективность выполнения сотрудниками органов внутренних дел своих функциональных обязанностей, безусловно, во многом определяется тем, насколько сами сотрудники в своих действиях руководствуются нормами служебной дисциплины и законности. На необходимость строжайшего соблюдения законности государственными служащими обращает особое внимание Президент России В. В. Путин [1]. Сообразно с этим актуальность рассматриваемых вопросов не вызывает сомнений.

В научной литературе анализу вопросов, связанных с соблюдением сотрудниками органов внутренних дел служебной дисциплины и законности, уделяется достаточно серьезное внимание, что позволяет говорить о достаточной изученности обозначенной проблематики [3; $4 ; 5 ; 6]$.

Основными нормативными правовыми актами в области организации и проведении работы по укреплению служебной дисциплины и законности среди личного состава органов внутренних дел на сегодняшний день являются:

- Федеральный закон от 25 декабря 2008 года № 273-Ф3 «О противодействии коррупции»,

— Федеральный закон от 7 февраля 2011 года № 3-Ф3 «О полиции», 
- Федеральный закон от 30 ноября 2011 года № 342-Ф3 «О службе в органах внутренних дел Российской Федерации и внесении изменений в отдельные законодательные акты Российской Федерации»,

- Указ Президента Российской Федерации от 14 октября 2012 года № 1377 «О Дисциплинарном уставе органов внутренних дел Российской Федерации»;

- Приказ МВД России от 26 июня 2020 года № 460 «Об утверждении Кодекса этики и служебного поведения сотрудников органов внутренних дел Российской Федерации»;

- Приказ МВД России от 26 марта 2013 года № 161 «Об утверждении Порядка проведения служебной проверки в органах, организациях и подразделениях Министерства внутренних дел Российской Федерации»;

- Методические рекомендации по организации моральнопсихологического обеспечения деятельности органов внутренних дел Российской Федерации: утверждены начальником ДГСК МВД России 10 октября 2018 года.

Работа по укреплению служебной дисциплины и законности среди личного состава является одним из видов морально-психологического обеспечения деятельности органов внутренних дел и представляет собой деятельность, направленную на профилактику и предупреждение правонарушений и чрезвычайных происшествий.

Анализ направлений, по которым проводится воспитательная работа по укреплению служебной дисциплины и законности в органах внутренних дел, позволяет утверждать, что она должна осуществляться комплексно, непрерывно, а также посредством реализации таких принципов как всеобщность (то есть ей должен охватываться весь личный состав) и дифференцированность (следует учитывать личные профессионально-нравственные качества отдельных сотрудников).

Методическими рекомендациями по организации морально-психологического обеспечения деятельности органов внутренних дел Российской Федерации установлены основные задачи, которые должны решаться при проведении воспитательной работы по укреплению служебной дисциплины и законности. Среди этих задач следует особо выделить доминирующую - обеспечение неукоснительного соблюдения сотрудниками конституционных норм и требований федерального законодательства. По нашему мнению, решив именно эту задачу, мы сможем беспрепятственно обеспечить решение других задач, поскольку обязательное соблюдение и исполнение норм служебной дисциплины и законности сотрудниками органов внутренних дел, несомненно, будет способствовать улучшению моральнопсихологического климата в коллективе, повышению уровня правосознания и правовой культуры сотрудников, воспитанию чувства ответственности за качество выполнения своих должностных обязанностей и т.д. Решением вышеуказанной задачи с нашей точки зрения будет являться повышение требовательности руководителей всех уровней в первую очередь к себе, а также к своим подчиненным и комплексное использование всех предусмотренных форм и методов воспитания личного состав (лекция, доклад, беседа, инструктаж, диспут, убеждение, пример, поощрение, принуждение и т.д.).

Таким образом, подводя итог вышеизложенному, можно констатировать следующее:

1) работа по укреплению служебной дисциплины и законности в органах внутренних дел имеет важнейшее значение с позиции подготовки сотрудников, способных по своим личным и деловым качествам эффективно и качественно выполнять свои непосредственные должностные обязанности [2, с. 141]; 
2) на наш взгляд совершенствование работы по укреплению служебной дисциплины и законности среди личного состава как вида моральнопсихологического обеспечения оперативно-служебной деятельности органов внутренних дел должно осуществляется исходя из следующих принципов:

- индивидуализация ответственности за нарушение ном служебной дисциплины и законности;

- комплексное использование всех предусмотренных форм и методов воспитания личного состава;

— акцентирование внимания на анализе причин и условий совершения сотрудниками органов внутренних дел дисциплинарных проступков и нарушения законности.

$$
* * *
$$

1. Послание Президента Российской Федерации Федеральному Собранию Российской Федерации от 15 января 2020 года // Российская газета, 2020, 16 января.

2. Бялт В. С., Трипутин С. Н. Воспитательная работа по укреплению служебной дисциплины и законности среди личного состава органов внутренних дел: актуальные проблемы и пути решения // Вестник Санкт-Петербургского университета МВД России. 2014. № 1 (61). С. 139-144.

3. Куликова Н. С. Внутриведомственный контроль как способ обеспечения законности и служебной дисциплины в органах внутренних дел // Вестник Воронежского института МВД России. 2015. № 4. C. $55-61$.

4. Сидорова М. В. Соотношение законности и дисциплины в деятельности сотрудников органов внутренних дел // Юридическая наука и правоохранительная практика. 2015. № 4(34) . С. 199-208.

5. Стригуненко Ю. В. Служебная дисциплина и законность в органах внутренних дел: понятие, основные компоненты и виды дисциплинарных отношений // Общество: политика, экономика, права. 2011. № 2 . С. 161-164.

6. Шаривзода М. С. Понятие, основные черты и значение законности и служебной дисциплины в органах внутренних дел // Труды Академии МВД Республики Таджикистан. 2019. № 1 (41) . С. $242-246$.

\section{Бялт В.С., Косолапов А.Д. \\ Воспитательная работа как вид морально-психологического обеспечения деятельности органов внутренних дел}

Санкт-Петербургский университет МВД России (Россия, Санкт-Петербург)

doi: 10.18411/lj-02-2021-125

idsp: ljournal-02-2021-125

\section{Аннотация}

Статья посвящена рассмотрению основных актуальных проблем воспитательной работы в органах внутренних дел как одного из видов морально-психологического обеспечения деятельности органов внутренних дел. В статье авторы, анализируя действующие правовые нормы в обозначенной сфере, исследуют основные направления воспитательной работы в органах внутренних дел, методы воспитания личного состава, а также формулируют и обосновывают ряд предложений по повышению эффективности воспитательной работы в органах внутренних дел.

Ключевые слова: воспитание; патриотизм; нравственность; моральнопсихологическое обеспечение; органы внутренних дел.

\section{Abstract}

The article is devoted to the consideration of the main topical problems of educational work in the internal Affairs bodies as one of the types of moral and psychological support for the activities of the internal Affairs bodies. In the article, the authors analyze the current legal 